\title{
The influence of full compliance with the Companies Act on the knowledge-creating potential of the directors' report
}

\author{
DG Gouws \\ Department of Accounting \\ and Finance \\ University of Pretoria
}

\author{
CJ Cronjé \\ Department of Applied \\ Accountancy \\ University of South Africa
}

\begin{abstract}
Accounting is a complex system, comprising numerous items and transactions that are interrelated in various ways. Management's decisions are reflected in accounting information. The user of accounting information has a real need to comprehend such information in order to make informed decisions. The research reported in this article reveals that when the directors' report fully complies with the letter and context of the Companies Act, it should be used as: a communication tool to enhance comprehensibility; as a mechanism to explain the economic reality of the company; and as a vehicle to reduce the gap between accounting information and the user. It should therefore be used as a knowledge-creating statement, which the various stakeholders of the company can tap into.
\end{abstract}

\section{Key words}

Directors' report Knowledge creation

Communication Comprehensibility

\section{Introduction and statement of the problem}

In an annual report, financial statements form part of the broader set of entity disclosures that range from the mission statement to the directors' report. While a great deal of research has been undertaken on the income statement, balance sheet and cash-flow statement, the directors' report has not been subjected to much investigation. Instead, attention has focused on the measurement and disclosure factors, maintaining interest in the accounts themselves instead of probing their knowledgecreating context. A restriction of this nature can limit the questions that 
can be asked about annual reports and the modes of comprehension to which they can be subjected. The question that is highlighted in this study is whether the directors' report can - in accordance with the legislator's intention - contribute towards stakeholders' comprehension of the financial statements and serve as an aid to decision making.

In this paper, the importance of the directors' report is recognised as a knowledge-creating vehicle. The first section of the paper discusses the accounting road to knowledge creation by focusing on processes for converting accounting data into knowledge; comprehensibility; the accounting language; and how the narrative potential of the directors' report can be utilised to create accounting knowledge. The second section describes the research methodology, research problem as well as the aims of the investigation. In the third section, a semantic and a contextual framework approach are followed to determine the intention of the legislator with regard to directors' reports. In the following section, international practices are compared. Thereafter follows the results of an investigation into the current status of the directors' report by means of an assessment guide. The paper concludes with a summary and the conclusions that are drawn.

\section{Knowledge-creation potential of the directors' report}

\subsection{Knowledge creation}

\subsubsection{Life cycle of accounting knowledge}

In this context, the term knowledge implies the entire 'understanding continuum' as defined by Gouws (2001) and encompasses the life cycle of accounting knowledge, including the process that transforms data into information and the process that transforms information into knowledge. It is evident from the conceptual framework as well as from the views of accounting bodies that the accounting-information system should provide information that meets the needs of its users. Before the various users of accounting information can use the information, they must be able to comprehend it - either by making it comprehensible for themselves or having it explained to them by experts.

A diagram of the process that occurs beyond the numbers to create knowledge can be represented as follows (Gouws 2001, adapted): 


\section{Diagram 1}

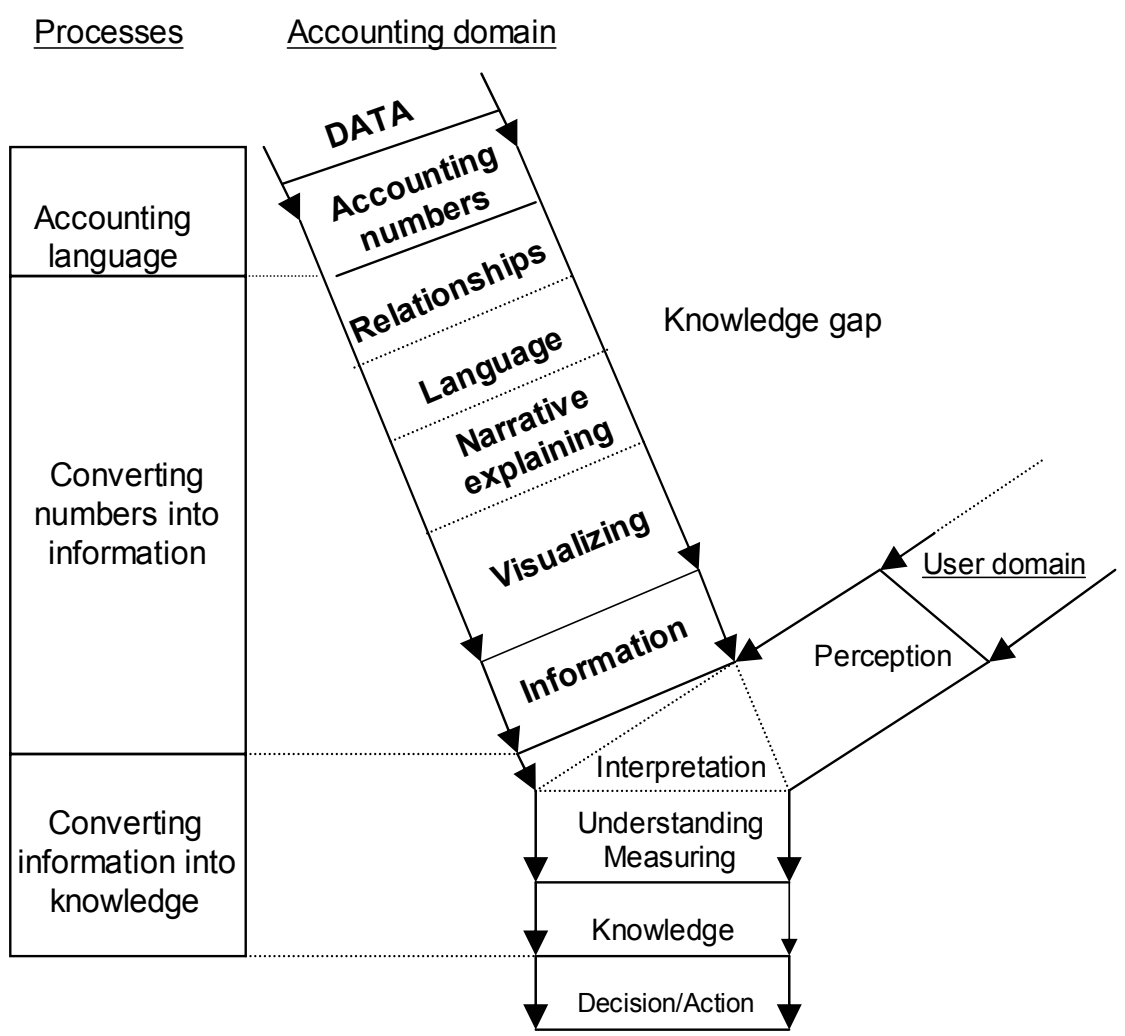

The main aim of the processes that occur beyond the data and numbers is to create knowledge. It is clear from the diagram that it is necessary to define the processes that engages users with the existing data and information in new ways. There is a need for an awareness of the knowledge life cycle that can enhance comprehension, learning and the use of accounting information. The creation of knowledge is not merely a matter of mechanistically processing or analysing data.

\subsubsection{Comprehensibility}

Financial information can have various degrees of comprehensibility. The quality of comprehensibility is a characteristic that is influenced by both the users and the preparers of accounting information. In the hierarchy of accounting qualities, comprehensibility is recognized as a user-specific quality (FASB 1980). Contemporary financial statements are often almost incomprehensible to anyone other than the preparers of the statements (Making Corporate Reports More Valuable 1988). Although accounting communication appears to be central to many of the definitions of accounting, the process in which accountants use the 
"accounting language" and accounting symbols to convey meaning to users has been neglected (Gouws 1997).

If a user is not closely associated with that which is disclosed in the accounting numbers, his or her ability to interpret the numbers will be restricted, and he or she may have a greater need for supplementary explaining to clarify a particular situation. This gap may be of an organisational, cognitive or geographical nature. It could be argued that accountants' priority should be to improve their ability to communicate understanding or comprehension rather than to increase the detail and complexity of their reports (Alexander 1990). The main aim of the process beyond the data and numbers is to create knowledge in order to bridge the knowledge gap between the entity and the users of the information. Gallhofer and Haslam (1991:492) argue that accounting's aura, " ... engenders an unquestioning acceptance of prevalent accounting numbers as conveyors of an unproblematic, concrete and valid message."

\subsubsection{The language issue}

Scientists accept that there are two levels at which their observations are conducted (Ryan, Scapens and Theobald 1993). At the lowest level of observation there can be a description of the facts to the extent that the "accounting language" permits. Accounting is known as the language of business. Belkaoui describes accounting as “... a language with lexical and grammatical structure where accounting terms are its vocabulary and accounting rules are its syntax." (In Bayou 1993:32).

The "accounting language" presupposes some theory of measurement. The approach to measurement in accounting assumes that money constitutes a unit of measure and that a monetary system constitutes a ratio scale. Neither of these propositions appears to be empirically verifiable. It is a fact that measurements improve observations and add to the informational content of observations by making them more precise, although precision lies in language as well as in numbers (Most 1977). Furthermore, the language of a social science (like Accounting) is malleable, permitting a wide diversity of meaning (Habermas 1972).

At the higher level, observation entails some interpretive language, which gives observational reports their significance. Language is the medium in which meanings are shared, not only in the cognitive sense, but also in the comprehensive sense of significance. Only statements of a pure language can be completely understood (Habermas 1972). It can be asked whether sufficient efforts are being carried out to make the accounting product more comprehensible. The directors' report (or a similar document) could be an ideal vehicle to accommodate the need of a user to comprehend the accounting product. 


\subsection{The narrative potential of the directors' report}

The chairman's statement and the directors' report that are included in the annual report are a rich source of data, although the informational content is open to dispute. Nevertheless, there is evidence that these sections of annual reports are amongst the most popular with investors and especially with those persons that lack financial training (Rees 1990). Several writers refer to the difficulty that users have to comprehend financial information, because of its complex nature. Overquantification is acute in financial statements, which are dominated by numerical data, calculations, measurements and ratios (Gouws \& Lucouw 1999). In recent years, the problem of users' comprehension has been a major concern to the preparers and the users of financial statements. The interpretation of financial data is a complex matter in which relatively few investors are skilled (Bernstein 1993). Cooper, Pheby, Pheby \& Puxty (1992) emphasise accounting's continuing distance from the public.

Accounting theorists have been searching for answers to these problems by offering various alternatives or suggesting solutions to the problems. Lee and Tweedie (1976:314) state that, in order to communicate effectively with all shareholders, less complex data should be presented to the users of financial information. The Cadbury Committee (Cadbury Report 1992, par. 4.51) also stated that effective disclosure should not be limited to figures and percentages. Everingham, in Griffiths (2000:145), commented that one of the most neglected areas in financial reporting by companies in South Africa is the lack of truly meaningful narrative commentary to support the figures. Narrative and explanatory type of disclosures in the directors' report could be used to address these limitations. The directors' report could be used as a knowledgecreating statement, which can be tapped into by the various stakeholders of a company.

\subsection{Legislator's intention with accounting}

Accounting regulation is mostly based on a system of detailed rules that are prescribed by the accounting standards and the law. However, rulebased systems can rarely be watertight. There could be loopholes in the rules and they could be vague or even incomplete. Of equal, if not greater, significance is the fact that companies may develop practices that fulfil the rules to the letter, but undermine their spirit (Shah 1996:23). For example, Reinecke (1996:12) believes that disclosure-driven corporate governance models are undermined by companies that do just enough to fulfil the disclosure requirements and thereby create the impression that they are adhering to good governance practices. In the post-war years, companies tended to provide detailed information about their operations in the chairman's statement rather than in the directors' report (Farmer 1986). Furthermore, it appears that contemporary 
reporting is done in a way that artfully avoids any possibility of additional liability for directors. A further reason for this tendency is probably that the information contained in the directors' report is subject to auditing. Some valuable information is either not provided or is disclosed elsewhere in the annual report.

This study was based on the conviction that the legislator's intention in section 299 can be considered to be a guide to the disclosure of information in such a way that it contributes to comprehension.

\section{Research methodology and aims}

\subsection{Research problem}

The research problem addressed in this study is whether full compliance with the letter and the context of the Companies Act, 1973 (Act 61 of 1973) (hereafter "the Act") can enhance the knowledge-creating potential of the directors' report. The hypothesis of the research was based on the fact that, although the letter and the context of the Act requires (by implication) the directors' report to be a knowledge-creating statement, the directors' report is not utilised for this purpose.

\subsection{Aims of the investigation}

The aims of the investigation are:

- $\quad$ To illustrate, by means of a semantic (the branch of linguistics dealing with the meanings of words and sentences) and a contextual approach, that the directors' report, which is part of the annual financial statements, should serve as a communication tool:

- $\quad$ To make the information in the financial statements more comprehensible.

- $\quad$ To reflect the economic reality of a company.

- To act as a mechanism for reducing the distance between the annual financial statements and the user.

- To investigate the legislation on the directors' report or similar reports in other countries in order to determine international trends and practices.

- To use an assessment guideline to establish whether the information contained in directors' reports complies with the suggested intention of the legislator. 


\subsection{Selection of data}

To determine the current status of directors' reports, listed companies on the J S E Securities Exchange were selected. Two industry sectors were selected randomly and all the companies in these industries were included. The industry sectors selected were:

- $\quad$ Electronics and electrical

- Retail.

Fifty-eight local companies were involved.

\section{A semantic and a contextual framework approach}

\subsection{Background}

To determine the intention of the legislator with regard to directors' reports, one of two approaches could be followed (Botha 1988:36):

- $\quad$ Firstly, the words could be analysed with the use of the literal approach, which is generally used in the interpretation of statutes (Cockram 1995). "The cardinal rule of constructing is that the words must be given their ordinary, literal and grammatical meaning." (Volschenk v Volschenk 1946).

- The second approach is that of the use of a contextual framework. In the use of this approach the objective is to comprehend the meaning of the words while simultaneously keeping the practical implications of the item in mind.

In this study, a semantic approach was first followed and thereafter a contextual framework approach. The first approach comprised an examination of the words of the relevant sections of the Act to determine their meaning with the use of the Oxford Advanced Learner's Dictionary 1998 (hereafter "Oxford 1998") and, thereafter, to find synonyms for the words in the Collins Thesaurus 1985 (hereafter "Collins 1985"). The second approach deals with the interpretation of the words in their context in order to establish what the legislator's intention was with the Act.

In terms of the Act, the directors' report should deal in narrative form with all descriptive matters under appropriate headings, and amounts or statistics should be set out, as far as practicable, in tabular form together with comparative figures for the previous period. The main purpose of the directors' report is to notify members of the company of all material matters concerning the state of affairs and the financial position of the company. The directors' report should provide information that is additional to the income statement and the balance sheet. As the directors' report forms an integral part of the annual financial statements, 
it should essentially serve to supplement the information contained in the annual financial statements (Cilliers \& Mans 1999).

\subsection{Interpretation of sections of the Act}

\subsubsection{Section 299(1)}

Section 299(1) states that : "... Every company ... shall submit, as part of its annual financial statements, a directors' report with respect to the (1) state of affairs, the business and income (profit) or loss of the company ... to the annual general meeting ...".

\section{(1) state of affairs:}

- Oxford 1998: a set of circumstances, a situation. Situation: a set of circumstances or conditions, especially at a certain time.

- Collins 1985: circumstances, condition, position, shape, situation, state of affairs.

Suggested intention of the legislator.

The term state of affairs indicates a set of circumstances at a particular time, but means more than merely focusing on the circumstances prevailing at the date of the financial statements. The terms condition and shape indicate the level of condition and not the position only.

\subsubsection{Section 299(2)}

Section 299(2) provides that: " ... The directors' report should deal with every (1) matter which is material to the (2) appreciation by the members of the state of affairs, the business and the income (or loss) of the company (or group of companies) and must for that purpose contain at least the information prescribed by Schedule 4 and comply with the requirements thereof (and of the Act) ...".

\section{(1) matter:}

- $\quad$ Oxford 1998: a topic or situation being considered.

- Collins 1985: substance, event, incident, occurrence, situation, transaction, amount, argument, context, problem, be of consequence, have influence, mean something.

Suggested intention of the legislator:

Every matter has a bearing on internal and external data/information about the business, which includes any material event, incident or occurrence of substance, argument or context that could enhance meaning. 
(2)

appreciation:

- Oxford 1998: a full or sympathetic understanding of something; gratitude for something; a written text or a discussion in which the quality or worth of somebody/something is assessed or judged.

- Collins 1985: assessment, awareness, comprehension, estimation, knowledge, perception, understanding, valuation, enhancement, improvement, criticism, notice.

Suggested intention of the legislator:

Appreciation is a human activity. It involves all substantial information that could have a bearing on the understanding, comprehension and awareness levels of members. It also has a bearing on the transformation of data into information. It is clear therefore that the Act provides for both the supply of information and the ability of the member or user to interpret or comprehend it, and it thereby provides an opportunity for contributing to knowledge creation.

\subsubsection{Paragraph 66(1)}

Paragraph 66(1) of Schedule 4 of the Act provides that: “...The directors' report shall deal in (1) narrative form with all (2) descriptive matters under appropriate headings and amounts or statistics shall be set out as far as practicable in tabular form ...".

(1) narrative:

- Oxford 1998: a spoken (verbal) or written account of events; a story.

- Collins 1985: account, detail, history, report, statement, story.

Suggested intention of the legislator:

Cilliers \& Mans (1999:241) state the following in this regard: "An important premise underlying the disclosure requirement of the Act is that in order to fairly present the state of affairs and the income or loss of the company, the figures contained in the balance sheet and the income statement must be accompanied by a narrative report - the directors' report - complementing and explaining those figures, where necessary". According to the above explanations, the term narrative means a verbal or written account of events. It covers a verbal or written "story" that explains and complements the annual financial statements.

(2) descriptive:

- Oxford 1998: giving a picture in words; describing something, especially without expressing feelings or 
judging - therefore not intruding on the members' right to interpret.

- Collins 1985: depictive, detailed, explanatory, expressive, graphic, illustrative, pictorial, picturesque.

Suggested intention of the legislator:

The term descriptive therefore means a picture in words, which is expressive and illustrative for the purpose of giving meaning to the numbers in the financial statements. Illustrative ways of expressing reality include graphs, pie charts and flow diagrams. The use of colour and metaphors can contribute to understanding. Nonaka (1998:33-34) suggests that "One kind of figurative language that is especially important is metaphor. By 'metaphor' I don't just mean a grammatical structure or allegorical expression. Rather, metaphor is a distinctive method of perception. It is a way for individuals grounded in different contexts and with different experiences to understand something intuitively through the use of imagination and symbols without the need for analysis or generalisation. Through metaphors, people put together what they know in new ways and begin to express what they know but cannot yet say. As such, metaphor is highly effective in fostering direct commitment to the creative process in the early stages of knowledge creation"

It is important to bear in mind that this activity should not intrude on a user's right to interpret. The right to interpret independently is a personal matter.

\subsubsection{Paragraph 66(2)}

Paragraph 66(2) of Schedule 4 of the Act provides that : “... Any further matter not prescribed by Schedule 4 but which is (1) material for the appreciation of the state of affairs of the company and of any subsidiary (and of the group) must be dealt with in the directors' report under appropriate headings ...."

\section{(1) material:}

- $\quad$ Oxford 1998: important, essential, relevant.

- Collins 1985: essential, important, indispensable, meaningful, significant, vital, substantial.

Suggested intention of the legislator:

All the matters and events that are important, essential, meaningful and relevant for understanding financial statements should be dealt with in the directors' report. 


\subsubsection{Paragraph 67(1)}

Paragraph $67(1)$ of Schedule 4 of the Act provides that: “...The said report shall generally review the business and operations of the company during the accounting period and the results thereof and shall deal with every (1) fact or (2) circumstance material to the appreciation of the state of the company's affairs by its members including a statement of the estimated proportion of profit or loss attributable to the various classes of business of the company...".

(1) fact:

- $\quad$ Oxford 1998: a thing that is known or can be proved to have happened, to be true or to exist; a situation or set of circumstances that exists; a piece of information on which a belief or an argument is based; what is true; reality.

- Collins 1985: act, deed, event, fait accompli, happening, incident, occurrence, performance, actuality, certainty.

Suggested intention of the legislator:

The term fact means information about an entity on which a belief or an argument is based and that is necessary for the purpose of understanding financial statements.

(2)

\section{circumstance:}

- Oxford 1998: a condition or fact connected with an event or action.

- Collins 1985: condition, contingency, detail, event, fact, happening, incident, item, occurrence, position, situation.

Suggested intention of the legislator:

The term circumstance means much the same as the term fact above, but has a wider connotation. "... meaning and significance come from and depend upon an understanding of the environment context from which the numbers are drawn as well as the relationship between the numbers and the underlying economic phenomena..." (Gouws \& Lucouw 1999).

\subsubsection{Summary}

In analysing the above, it could be concluded that every company is required to submit a written account of events in the form of a directors' report, which encompasses all material circumstances and business activities. The directors' report should deal with material matters, which could impact on the decisions of members or users. It should be presented in a manner that transforms data into information and facilitates the comprehension of the users in a narrative, explanatory, 
illustrative, expressive and pictorial manner, which could include graphics, in order to give meaning to the numbers disclosed in the financial statements.

It should be noted that the substance that should feature in the directors' report is information. Wilson (1996) has stated that by selecting and analysing data, information can be produced, and by selecting and combining information, knowledge can be generated. Data should therefore be transformed into information by means of the directors' report with the aim of making it meaningful for the members/users. However, interpretation of the information is not permitted, because interpretation would encroach on the members' right to interpret.

Having investigated the intended meaning of the Act as far as the directors' report is concerned, it can be concluded that it was the legislator's intention that the directors' report should be used as a communication tool, which makes information more comprehensible. The distance between the company and the user (created by the inherent limitations of accounting data) and the apparent inability of members to comprehend and use the information should be attended to.

Two issues were highlighted in the preceding discussion, namely:

- $\quad$ There is a need for a medium that can facilitate comprehension of financial information.

- The directors' report, or a similar report, could fulfil this function. It is, however, required of the directors' report to fulfil this function.

The various dimensions of the directors' report that were identified above, in terms of the suggested intention of the legislator, are presented in the following diagram:

Full compliance with the Act

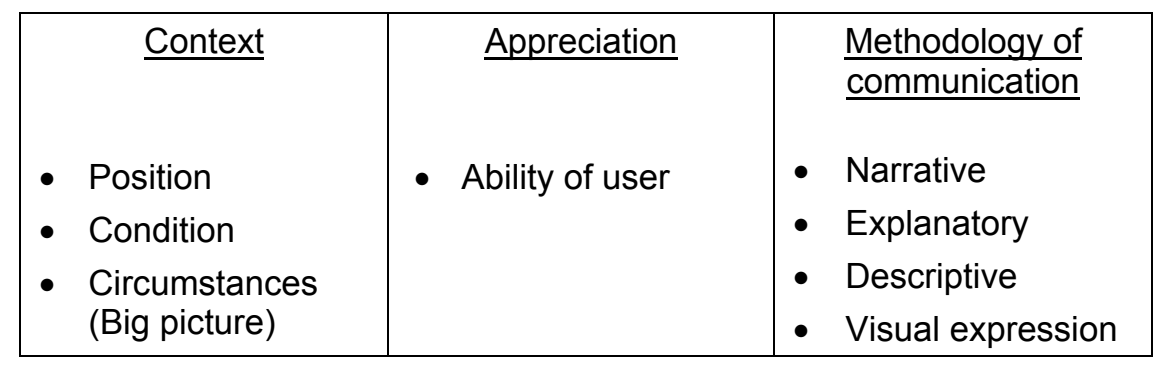




\section{$5 \quad$ Directors' report: international practices}

\subsection{Status of legislation in various countries}

In order to determine international trends and practices, a comparison was made of legislation in other countries concerning directors' reports. It was found that 24 countries out of a total of 43 have no legislation that requires the inclusion of a directors' report in the annual financial statements (Coopers \& Lybrand 1993). This finding clearly indicates that there is little consensus among countries concerning the apparent contribution that a directors' report, or a similar document, could make to bridging the comprehension gap between the preparers and the users of financial statements.

\subsection{Other reports required in other countries}

Besides the nineteen countries that have legislation that requires companies to include a directors' report, a further six countries have legislation that requires another type of report that may be considered to be a substitute for the directors' report. These reports were referred to as follows:

- A management discussion and analysis report (United States of America)

- $\quad$ A report from the administration board (Brazil)

- A management report (Germany)

- $\quad$ A business report (Japan and Austria)

- $\quad$ An administration report (Sweden)

\subsection{Summary}

As legislation in six countries requires a different type of discussion document and legislation in nineteen countries requires a directors' report, it may be assumed that there is no need for a type of discussion document other than the traditional annual financial statements. Many countries require more information in the directors' report than that which is required by South African legislation. The legislation of these countries requires inter alia disclosure of the entity's involvement in its social environment as well as information on its employees.

However, the latest international trend is towards the requirement that a management discussion and analysis (M D \& A) should be included in the annual report. According to Wolk, Tearney and Dodd (2000:308), the Securities and Exchange Commission (SEC) of the United States of America requires firms to provide readers with a prospective view of operations and cash flows by means of the M D \& A. Information of both a retrospective and a prospective nature is required. 


\section{$6 \quad$ Current status of directors' reports}

\subsection{Degree of full compliance}

An assessment guideline was developed to establish whether information contained in directors' reports complies with the suggested intention of the legislator (refer paragraph 4.2.6). The following aspects were assessed:

1. Context

- $\quad$ Circumstances (big picture)

- $\quad$ Financial position

- $\quad$ Financial condition

2. Apprehension of the user

- $\quad$ Ability to comprehend

3. Methodology of disclosure
- Narrative
- $\quad$ Explanatory
- Descriptive
- Visual expression

\subsection{Research results}

All the directors' reports were examined to establish whether the reports comply with the above guideline. The results of the examination are tabulated below.

\begin{tabular}{|c|c|c|c|}
\hline & \multicolumn{3}{|c|}{$\begin{array}{c}\text { Utilisation of the knowledge-creating } \\
\text { potential }\end{array}$} \\
\hline & $\begin{array}{c}\text { No } \\
\text { knowledge } \\
\text { creation }\end{array}$ & $\begin{array}{c}\text { Partial } \\
\text { knowledge } \\
\text { creation }\end{array}$ & $\begin{array}{c}\text { Full } \\
\text { knowledge } \\
\text { creation }\end{array}$ \\
\hline $\begin{array}{l}\text { 1. Context } \\
\text { - Circumstances (big } \\
\text { picture) } \\
\text { - Financial position } \\
\text { - Financial condition } \\
\text { 2. Apprehension of the user } \\
\text { - Ability to comprehend } \\
\text { 3. Methodology of } \\
\text { disclosure } \\
\text { - Narrative } \\
\text { - Explanatory } \\
\text { - Descriptive } \\
\text { - Visual expression }\end{array}$ & $\begin{array}{l}x \\
x\end{array}$ & $\begin{array}{l}X \\
X\end{array}$ & \\
\hline
\end{tabular}


None of the directors' reports examined fully complied with the letter and context of the Act. This finding means that companies are not adequately utilising the knowledge-creating ability of the directors' report.

\subsection{Research results regarding quality}

It appears that the disclosure of information in directors' reports does not fulfil expectations. There is a significant variation in the quality of the directors' reports of the companies concerned. An unacceptable number of companies, particularly the smaller companies, provide a generalised review of the financial results and ratios by merely stating in words the information reflected in the figures in the annual financial statements. Voluntary provision of information is limited and it appears that companies disclose just enough information in the directors' report to comply with legislation.

The directors' report can include a more detailed and informative management discussion and analysis, as required in the United States, where a management discussion and analysis report (MD\&A) is issued instead of a directors' report. The MD\&A provides management with a potentially rich and flexible communication medium. Its open-ended format creates latitude for subtle, textured, future-oriented and understandable communication. Unlike the more formal financial statements, which are highly constrained by the technicalities of Generally Accepted Accounting Practice, management has the opportunity - through the MD\&A - to tell its "story." The Executive Summary of SAICA 1997 summarises its conclusions as follows:"... it should thus include a discussion and interpretation of the business...".

\section{$7 \quad$ Summary and conclusions}

This study reveals that the directors' report is underutilised and can be used as an instrument for addressing the inherent limitations of accounting data and the inability of the members of a company to comprehend and use that information. If the letter and context of the intention of the legislator is analysed, the directors' report should be used as a communication tool to enhance understanding; as a mechanism to explain the economic reality (big picture) of a company; and as a vehicle to reduce the distance between accounting information and the user. Stakeholders are demanding greater accountability from a company's board of directors (Griffiths 2000:144).

When considering the objectives of financial statements, the importance of communication emerges. The directors' report is the mechanism by means of which information is conveyed to proprietors about the activities and status of their entities. The directors' report should be compiled in such a way that stakeholders (users) can get what they want from it without having to turn to an accountant for advice (ICAS 1988). 
The directors' report should make the information in the financial statements more comprehensible, because the conceptual basis that underlies the production of financial statements appears to defy the normal comprehension of financial affairs (ICAS 1988). The directors and senior managers of an entity should be in possession of facts about their entity in a comprehensible form. The source of information that has the highest ranking is direct personal contact with company management (Barker 1998). The Financial Accounting Standards Board (FASB 1978) recognises the obligation of management to increase the comprehensibility of financial information. In presenting information in financial statements, it should be borne in mind that stakeholders are not equally numerate. It is probable that many of them find it helpful if the information is presented descriptively rather than numerically.

The directors' report need not be prepared for either the layman or the financially illiterate person. Because the intelligibility or comprehensibility of proposed information is dependent on the nature of the user, this characteristic is classified as user specific (Hendriksen \& Van Breda 1991:131). The information should be comprehensible to a reasonable person. To enhance comprehension, the directors' report could include a statement that an assessor had agreed with the board of directors' on the non-disclosure of certain information, the publication of which could lead to a competitive disadvantage. As the currently published accounts are normally not suited to making fundamental decisions, the information contained in the directors' report should be as comprehensive as possible.

The directors' report should present the big picture of a company. The directors, being the persons responsible for the report and for managing the company, should know more about how it is performing and how it is likely to perform in the future than persons that have no daily contact with the company and whose knowledge is dependent upon what the insiders are willing to tell them. Some of the information that management withholds becomes public when management requires something (e.g. if additional capital is required or management wishes to defend or promote a take-over) (ICAS 1988). For fear of giving hostages to fortune, most management unfortunately limit to the minimum the disclosure of information required by prevailing regulations.

A useful guide on effective stakeholder communication is contained in a document that forms part of SAICA's Corporate Governance Series. It is entitled Stakeholder Communication in the Annual Report (SAICA 1997). The guide summarises its conclusions as follows: "[The narrative] overview should be seen as an opportunity for the directors to discuss a more expansive foundation on which to base their discussions. It should thus include a discussion and interpretation of the business, its financial structure, and the factors relevant to an assessment of future prospects. Trends and changes should be analysed, and not merely presented as an extraction of increases, decreases and percentages. The information 
should be presented in an unambiguous manner that it may be understood by the average stakeholder. It should be objective and unbiased dealing with positive and negative aspects".

This research indicates that, although the provisions of the Act place a burden on the directors, that are responsible for the directors' report, and on the auditors, that are responsible for auditing and for reporting on it, the directors' report (or a similar statement) could become a new and exciting hope on the user's horizon by enhancing his/her knowledge base.

\section{Bibliography}

Alexander, D.J.A. 1990. Financial Reporting, 2nd edition, Van Nostrand Reinhold (UK) Co. Ltd, England.

Barker, R.G. 1998. The market for information-evidence from finance directors, analysts and fund managers, Accounting and Business Research, Vol. 29, No. 1, pp.3-20.

Bernstein, L.A. 1993. Financial statement analysis. Theory, application and interpretation, 5th edition, Irwin, Homewood, Illinois.

Belkaoui, A. 1981. Accounting Theory, Second edition, Harcourt Brace Jovanovitch, International edition, USA.

Botha, C.J. 1988. Wetsuitleg, 2nd edition.

Cadbury Report, The, see Cadbury, Sir A. 1992.

Cadbury, Sir A. 1992. Committee on the financial aspects of corporate governance, The Committee on the Financial Aspects of Corporate Governance, Gee and Co. Ltd., London.

Cilliers, H.S. and Mans, K. N. 1999. Corporate Financial Reporting, Student edition, Butterworths, Durban.

Cockram, G.M. 1995. Interpretation of Statutes, 3rd edition.

Collins 1985 see McLeod, W.T. 1985.

Cooper, C., Pheby, D., Pheby, K. \& Puxty, A. 1992. Accounting, Truth and Beauty, Unpublished working paper.

Coopers and Lybrand. 1993. International Accounting Summaries, 1991 \& 1992 Supplement, Vol. 4. 
Epstein, M. J. and Pava, M. L. 1993. The Shareholder's use of Corporate Annual Reports, JAI Press Inc., Greenwich, Connecticut.

Farmer, E.R. 1986. Making sense of Company Reports, Van Nostrand Reinold (UK) Co. Ltd, London.

Financial Accounting Standards Board. 1978. Statement of Financial Accounting Concepts No.1, Objectives of Financial Reporting by Business Enterprises, November, 1978.

Financial Accounting Standards Board. 1980. Qualitive Characteristics of accounting information, No. 2, Statements of financial accounting concepts.

Galhofer, S. and Haslam, J. 1991. The Aura of Accounting in the context of a Crisis, Accounting, Organizations and Society, pp.487-520.

Gouws, D.G. 2001. Life-cycle of accounting knowledge, Unpublished working paper.

Gouws, D.G. and Lucouw, P. 1999. The process beyond the numbers and ratios, Meditari Accountancy Journal, Butterworths, Durban, pp.99122.

Gouws, D.G. 1997. Perspectives surrounding accounting communication, Meditari Accountancy Journal, Butterworths, Durban, pp.61-82.

Griffiths, G.A. 2000. Corporate Governance Principles, Potchefstroom University for Christian Higher Education, Unpublished M Com. Dissertation, Vanderbijlpark.

Habermas, J. 1972. Knowledge and human interests, Heinemann, London.

Hendriksen, E.S. and Van Breda, M.F. 1991. Accounting Theory, 5th edition, Irwin, Boston.

Hornsby, A.S. 1988. Oxford Advanced Learner's Dictionary of current English, 5th edition, Oxford University Press.

Lee, T.A. and Tweedy, D.P. 1976. The private shareholder: His sources of financial information and his understanding of reporting practices, Accounting and Business Research, Autumn 1976.

McLeod, W.T. 1985. The New Collins Thesaurus, Guild Publishing, London.

Most, KS. 1977. Accounting theory, Grid Inc., Columbus, Ohio. 
Nonaka, I. 1998. The Knowledge-Creating Company, Harvard Business Review on Knowledge Management, Harvard Business School Press, Boston.

Oxford 1998 see Hornsby, A.S. 1998.

Rees, B. 1990. Financial Analysis, Prentice-Hall, New York.

Reinecke, M. 1996. Kyk anders na korporatiewe regering, Finansies \& Tegniek, 14 June, p12.

Ryan, B., Scapens, R.W. \& Theobald, M. 1993. Research method and Methodology in Finance and Accounting, Academic Press, London.

Shah, A.K. 1996. Creative compliance in financial reporting, Accounting, Organizations and Society, Vol. 21, No. 1, Elsevier Science Ltd, Great Britain, pp.22-39.

South African Institute of Chartered Accountants. January 1997. Stakeholder Communication in the annual report, Johannesburg.

The Canadian Institute of Chartered Accountants. 1991. Information to be included in the annual report to shareholders, The Canadian Institute of Chartered Accountants, Canada.

The Institute of Chartered Accountants of Scotland. 1988. Making Corporate Reports Valuable, Kogan Page Limited, Great Britain.

Volschenk v Volschenk. 1946. CPD 486 on p.487.

Wilson, D. A. 1996. Managing Knowledge, Butterworth-Heinemann, Oxford.

Wolk, H.I., Tearney, M.G. and Dodd, J.L. 2000. Accounting Theory, A Conceptual and Institutional Approach, 5th edition, South Western College Publishing, Australia. 